Journal of Engineering and Applied Sciences 14 (Special Issue 5): 8944-8948, 2019

ISSN: 1816-949X

(C) Medwell Journals, 2019

\title{
Electricity Generation Using Photoelectric Power
}

\author{
Emad Jadeen Abdualsada Alshebaney, Maytham Khudhair Abbas \\ and Amjed Hassoon Saleh \\ Department of Chemical Engineering, College of Engineering, \\ University of Al-Qadisiyah, Iraq
}

\begin{abstract}
In this article the production of electricity using photoelectric power is discussed, the principle of photoelectric cells is described, a comparison of their performance depending on the type and material is conducted and analytical expressions describing the principle of operation of a solar power plant are presented.
\end{abstract}

Key words: Photoelectric cell, energy production, power

\section{INTRODUCTION}

Almost all currently existing methods of generating electricity are of the same nature. Power plants which use coal, natural gas or nuclear fuel are used to heat water to obtain high-pressure steam, which is used to turn a steam turbine, connected to the alternator.

Electricity production due to the use of photoelectric power is fundamentally different from other types of electric power generation, since the production of electricity due to photoelectric power eliminates the need for a turbine and a generator-electric power is produced by photoelectric modules (solar panels) which do not have any mechanical parts that are subject to wear (Islam et al., 2014; Batista et al., 2013).

The amount of energy received by the Earth in just one hour is more than what the population of the planet needs throughout the year. The total flow of solar energy, intercepted by the Earth on any particular day, is $4.2 \times 1018$ Watt hour, or $1.5 \times 1022 \mathrm{~J}$ (or $6,16 \times 1020 \mathrm{~J} \mathrm{~h}^{-1}$ ). This is equivalent to burning 360 billion tons of oil per day, or 15 billion tons per hour.

The actual total consumption of all forms of energy in the world is in average only $4.24 \times 1020 \mathrm{~J}$. according to this, the use of photoelectric power plants is one of the main directions of development of electric power industry.

The purpose of this article is to conduct a comparative analysis of the performance of photoelectric cells, depending on the type and material.

\section{MATERIALS AND METHODS}

Sunlight consists of photons or particles of solar energy. These photons contain different amounts of energy corresponding to different wavelengths of the solar spectrum (Fig. 1).

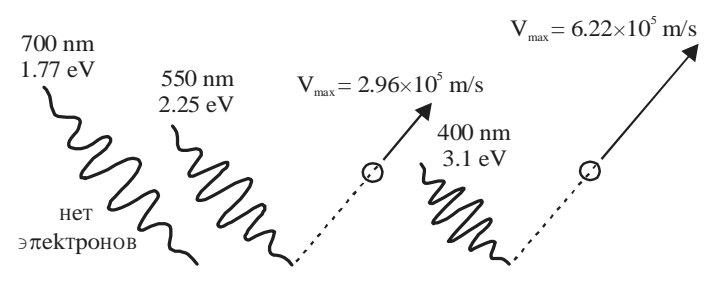

Fig. 1: The amount of energy depending on the wavelength

When photons strike a photoelectric cell, they can be reflected, pass directly or be absorbed, while the absorbed photons provide energy to generate electricity.

When a sufficient amount of solar light (energy) is absorbed by material (semiconductor), electrons are displaced from the atoms of the material (Fig. 2). A Special surface treatment to the material of photoelectric cell, at production, makes it more susceptible to free electrons, therefore electrons naturally migrate to the surface. When the electrons are moving, each of them carries a negative charge, holes on the front surface of the cell are formed and the charge imbalance between the front and back surfaces arises and produces a voltage potential, such as positive and negative battery terminals. When connecting surfaces through an external load, an electric current occurs (Inganas and Sundstrom, 2016).

The interaction of photons with the material of the photoelectric cell (element) is determined by the well-known expression:

$$
\mathrm{E} \varphi=\mathrm{h} v
$$

Where:

$\mathrm{E}_{\Phi}=$ Energy of absorbed photons

$\mathrm{h}=$ Planck's constant $\left(6.63 \times 10^{-34}\right)$

$v=$ Frequency of electromagnetic radiation (sunlight)

Corresponding Author: Emad Jadeen Abdualsada Alshebaney, Department of Chemical Engineering, College of Engineering, University of Al-Qadisiyah, Iraq 


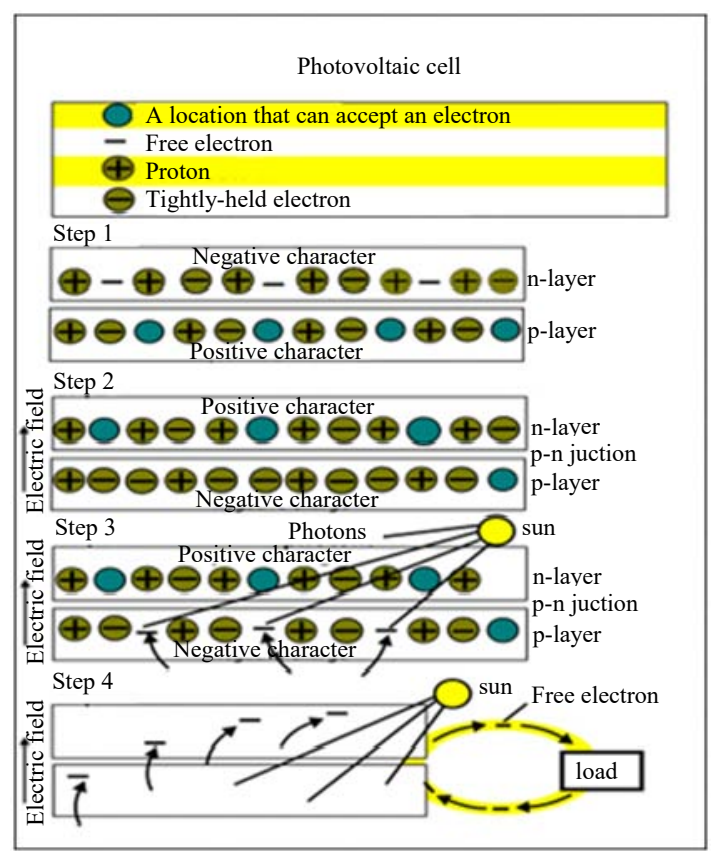

Fig. 2: Photoelectric cell operation

Although, the simplicity of the operating principle, photoelectric modules have a very complicated structure. Let us consider the main types and methods of manufacturing photoelectric elements in more detail.

Types of photoelectrical cells: Photoelectric cells or photocell can be made in various ways and from different materials. Despite this difference, they all perform the same task of collecting solar energy and converting it into usable electricity. The most common material for the design of solar panels is silicon, which has semi-conductive properties (Hussain and Uzair, 2013). Combining photocells in one body form solar panels from which a photoelectric array is made up in further.

Currently there are several technology types of manufacturing the photoelectric cell: monocrystalline silicon, polycrystalline silicon, thin silicon films, cadmium telluride elements ( $\mathrm{CdTe}$ ) and high efficiency photoelectric technology (gallium arsenide (GaAs) multi junction elements).

The first commercially available photoelectric cells were made of monocrystalline silicon, which is an extremely pure form of silicon. To obtain them, the inoculating crystal is drawn out of the mass of molten silicon, creating a cylindrical bullion with a single continuous crystal lattice structure. Then this crystal is mechanically sawn into thin plates $200-250$ microns thick, polished and processed to create the required $p-n$ junction with minimal reflection. After the anti-reflective coating is added and the front and back metal contacts are connected, the cell is assembled and packed together with

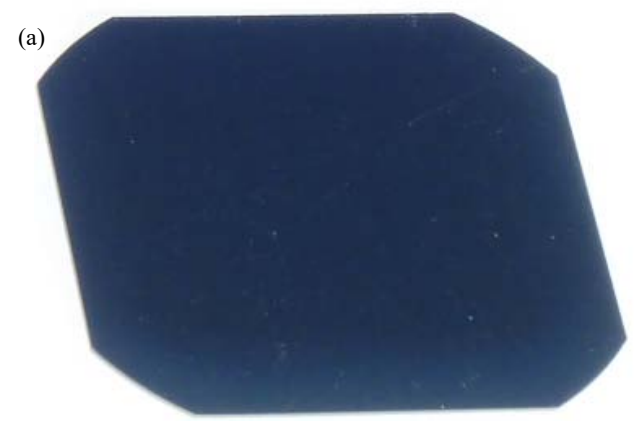

(b)

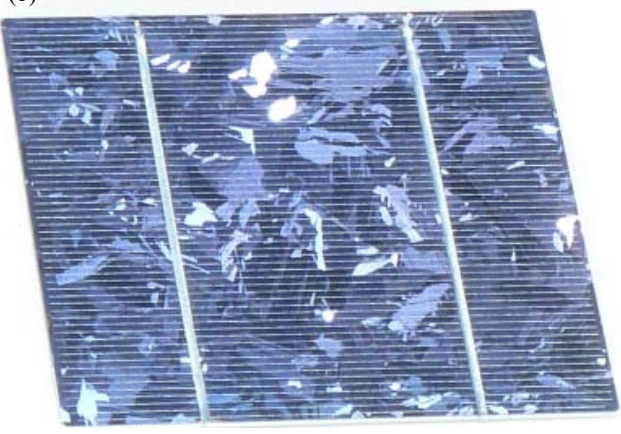

Fig. 3(a-b): Silicon elements (a) Single crystal and (b) Polycrystalline

other cells in the solar panel (Anonymous, 2015). Production of monocrystalline silicon photocell panels, despite their effectiveness, is a slow, laborious and expensive process in comparison with polycrystalline or thin-film analogs. The price of such modules is about $53 \mathrm{rub} / \mathrm{w}$ and Modules manufactured using this technology are typically characterized by uniform dark blue color (Fig. 3a) (Islam et al., 2014).

Polycrystalline silicon cell is made of silicon bullion containing many small crystal grains (Fig. 3b). The obtained plates, by this way, have a square shape with a thickness of 180-300 microns. Polycrystalline silicon photocells are cheaper but less effective in comparison with a monocrystalline thus currently more than $70 \%$ of photocells in the market are polycrystalline. Modules cost is $50 \mathrm{rub} / \mathrm{w}$.

Photocells can also be made in the form of thin films, which makes them more flexible and durable. One of the thin-film photocell types is an amorphous silicon (a-Si), which is formed by the deposition of thin layers of silicon on a transparent substrate. The result is a very thin and flexible cell, wherein less than $1 \%$ silicon is used, which is necessary for creating crystalline photocell. The surface of the semiconductor film has a thickness of several microns relative to crystalline silicon cells, which are several hundred microns (Anonymous, 2017).

Due to the small amount of raw materials required and the less energy required for the production process, amorphous silicon cells have a low production cost 
but their efficiency is much lower because silicon atoms are less ordered than in crystalline forms, which leads to the presence of electrically inactive bonds. Another disadvantage of photocell films is a $20 \%$ reduction in efficiency during the first few months of operation until stabilization, therefore, for photocell films, at selling stage, indicate the power rating with "Degradation" layer (Peake, 2018).

Production of photoelectric cells from cadmium telluride ( $\mathrm{CdTe}$ ) on a large scale due to the environmental problems of $\mathrm{CdTe}$, contained in the cell of cadmium telluride (CdTe) is insoluble in water and more stable than other compounds containing cadmium, it can be a problem with incorrect processing and disposal. CdTe photocells have higher efficiency than amorphous silicon photocells, with a slightly higher power cost 44-47 RUB/w.

Silicon, as noted above, is not the only material suitable for the manufacture of crystalline photocells. Gallium arsenide (GaAs) is an alternative semiconductor that is very suitable for applications in photoelectric cells. Gallium arsenide has a similar crystalline structure to that one of monocrystalline silicon but with varying gallium and arsenic atoms (Ren et al., 2017). Because of its higher light absorption coefficient and wider bandgap, GaAs cells are much more efficient than silicon cells. In addition, GaAs cells can operate at much higher temperatures without significant deterioration of characteristics that make them suitable for concentrated photo cells. GaAs are formed by deposition of gallium and arsenic layers on the base of a single crystal, which determines the orientation of the new crystal growth. This process makes GaAs photoelectric cells much more expensive than silicon cells and it is reasonable to use them only when high efficiency is required, for example, in space technologies (Kang et al., 2013).

\section{DISCUSSION}

Table 1 shows a comparison of photovoltaic cells from different materials.

Electric power generation: A photoelectric cell can be viewed as a current generator, the equivalent circuit of which is shown in Fig. 4. The current $I$ at the output terminals equal to the current, generated by the photoelectric effect, $I_{g}$ of the ideal current generator, reduced by the diode current $I_{d}$ and a leakage current $I_{1}$. Resistance $\mathrm{R}_{\mathrm{s}}$ is the internal resistance to the flow of the generated current and depends on the thickness $\mathrm{p}-\mathrm{n}$ junction, existing impurities and contact resistances. Leakage conductance $G_{1}$ takes into account the current that goes to the ground under normal operating conditions. In an ideal cell, we would have $R_{s}=0$ and $\mathrm{G}_{1}=0$.

In reality, for high-quality silicon cells, we have $\mathrm{R}_{\mathrm{s}}=0,05 \div 0,10$ OM and $\mathrm{G}_{1}=3 \div 5 \mathrm{MOM}^{-1}$.

The efficiency of photocells conversion strongly depends on a small variation of $R_{s}$, whereas the change in $\mathrm{G}_{1}$ affects it much less.

The open circuit voltage $V_{o c}$, arises when the load does not absorb the current $(I=0)$, is determined by the relation:

$$
\mathrm{V}_{\mathrm{OC}}=\frac{\mathrm{I}_{1}}{\mathrm{G}_{\mathrm{I}}}
$$

The current of the diode is determined in accordance with the classical expression for constant current:

$$
I_{d}=I_{D} \times\left[\frac{Q \times V_{O C}}{e^{A \times k \times T}}-1\right]
$$

Where:

$\mathrm{I}_{\mathrm{D}}=$ Diode saturation current

$\mathrm{Q}=$ Electron charge $\left(1.6 \times 10^{-19} \mathrm{~K}\right)$

$\mathrm{A}=$ Diode identity coefficient depending on recombination coefficient inside the diode (for crystalline silicon is -2)

$\mathrm{k}=$ Boltzmann constant $\left(1.38 \times 10^{-23} \mathrm{~J} / \mathrm{K}\right)$

$\mathrm{T}=$ Absolute temperature in in ${ }^{\circ} \mathrm{K}$

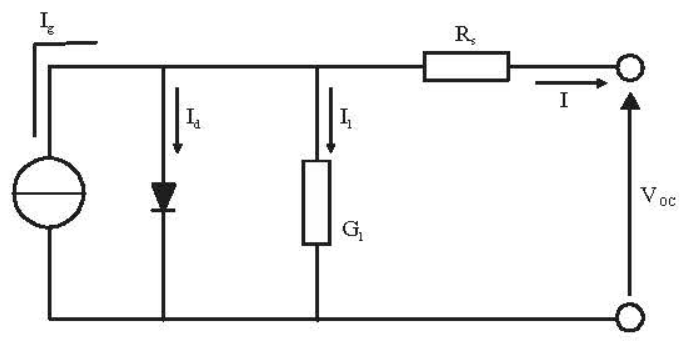

Fig. 4: Equivalent circuit of a photoelectric cell

Table 1: Comparison of photoelectric cells

\begin{tabular}{llllll}
\hline Parameter & Mono crystal & Poly crystal 1 & Amorphous silicon & CdTe & GaAs \\
\hline Efficiency & $16-17 \%$ & $14-16 \%$ & $7-8 \%$ & $12.4-13.4 \%$ & $32.5 \%$ \\
\hline Advantages & $\begin{array}{l}\text { High permanent } \\
\text { efficiency, reliable }\end{array}$ & $\begin{array}{l}\text { Low cost, ease of } \\
\text { production, optimal } \\
\text { overall dimensions }\end{array}$ & $\begin{array}{l}\text { Lower cost, lower } \\
\text { sensitive to the temperature } \\
\text { effect, higher output pow er }\end{array}$ & Low cost & $\begin{array}{l}\text { Resistance to high } \\
\text { temperatures }\end{array}$ \\
\hline $\begin{array}{l}\text { Disadvantages } \\
\text { Higher amount of } \\
\begin{array}{l}\text { energy needed for } \\
\text { production }\end{array}\end{array}$ & $\begin{array}{l}\text { Sensitive to impurities } \\
\text { in the manufacturing } \\
\text { stage }\end{array}$ & $\begin{array}{l}\text { Large size, construction } \\
\text { cost and assembly time }\end{array}$ & $\begin{array}{l}\text { Toxicity, inaccessibility } \\
\text { of materials }\end{array}$ & $\begin{array}{l}\text { Toxicity, inaccessibility } \\
\text { of materials }\end{array}$ \\
\hline
\end{tabular}


The load current is determined by the following expression:

$$
\mathrm{I}=\mathrm{I}_{\mathrm{g}}-\mathrm{I}_{\mathrm{d}}-\mathrm{I}_{1}=\mathrm{I}_{\mathrm{g}}-\mathrm{I}_{\mathrm{D}} \times\left[\frac{\mathrm{Q} \times \mathrm{V}_{\mathrm{OC}}}{\mathrm{e}^{\mathrm{A} \times \mathrm{k} \times \mathrm{T}}}-1\right]-\mathrm{G}_{\mathrm{I}} \times \mathrm{V}_{\mathrm{OC}}
$$

In ordinary cells, the last term of this expression, that is, the leakage current to earth $\mathrm{I}_{1}$, is negligible with respect to the two other currents. As a consequence, the saturation current of the diode can be experimentally determined from an open circuit for a $V_{o c}$ unlit cell and by measuring the current flowing inside the cell.

The current-voltage curve characteristic of the photocell is shown in Fig. 5. Under short-circuit conditions, the generated current is at the highest level $\left(I_{s c}\right)$, whereas with an open circuit, the voltage $\left(\mathrm{V}_{o c}=\right.$ Open circuit voltage $)$ is at the highest level.

Under the mentioned above two conditions, the electrical power generated in the cell is zero, while under all other conditions, when the voltage rises, the generated power also rises: firstly, it reaches the maximum power point $(\mathrm{PM})$ and then drops suddenly near the open circuit voltage value.

Volt-ampere photocell curve characteristic has the following points:

$I_{s c}$ : Short circuit current

$\mathrm{V}_{o c}$ : Open circuit voltage

$\mathrm{Pm}$ : Maximum power under standard conditions

$I_{m}$ : The current created at maximum power

$\mathrm{Vm}$ : Voltage at the point of maximum power

A power plant operating on solar energy, connected to the grid and supplying the installation of the consumer, can be represented by a simplified diagram, shown in Fig. 6.

When the intensity of sunlight is high, the generated current $I_{g}$ may exceed required by the load $I_{u}$, the current $\mathrm{I}_{\mathrm{r}}$ becomes negative and is no longer consumed from the circuit and is introduced into it. For the diagram, it is possible to write the following expressions:

Power consumed by user:

$$
\mathrm{P}_{\mathrm{U}}=\mathrm{U} \times \mathrm{I}_{\mathrm{u}}=\frac{\mathrm{U}^{2}}{\mathrm{R}^{u}}
$$

Power generated by the power plant:

$$
\mathrm{P}_{\mathrm{g}}=\mathrm{U} \times \mathrm{I}_{\mathrm{g}}
$$

The power transmitted by the grid:

Knowing the average annual power of solar radiation $E_{m a}$, one can calculate the expected amount of energy $E_{p}$ using The following expression:

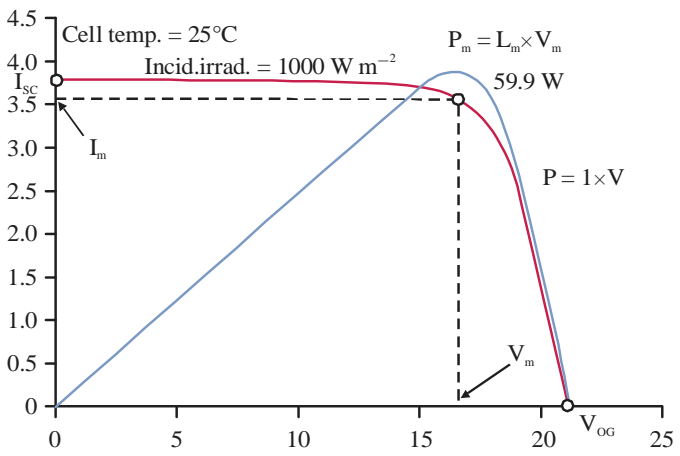

Fig. 5: Volt-ampere photocell curve characteristic

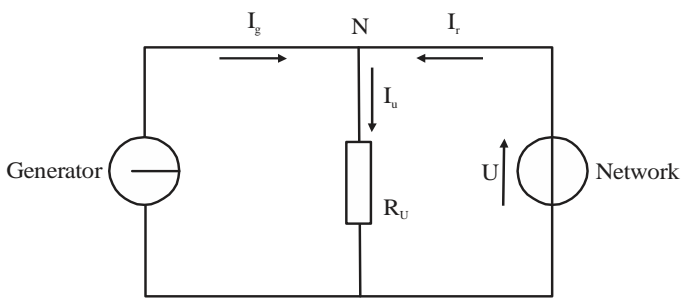

Fig. 6: Power plant with a grid

$$
\mathrm{E}_{\mathrm{P}}=\mathrm{P}_{\mathrm{g}} \times \mathrm{E}_{\mathrm{ma}} \times \eta_{\mathrm{BOS}}
$$

where, $\mathrm{E}_{\mathrm{ma}}$ is the average annual power of solar radiation, $\mathrm{kWh} / \mathrm{m}^{2}, \eta_{\mathrm{BOS}}$ is the overall efficiency of all components of a photoelectric system on the load side (inverter, connections, losses due to temperature effect, loss due to shading and low solar radiation, loss due to reflection). The value of the efficiency parameter can vary from 0.75-0.85.

As an example, we calculated the power output of a power plant with photo panels with a total power of $3 \mathrm{~kW}$ and a productivity of $1 \mathrm{~kW} / \mathrm{m}^{2}$ installed in Sochi, if the average annual solar radiation power is $1365.1 \mathrm{kWh} / \mathrm{m}^{2}$ with an installation component efficiency of 0.75 :

$$
\mathrm{E}_{\mathrm{P}}=\mathrm{P}_{\mathrm{g}} \times \mathrm{E}_{\mathrm{ma}} \times \eta_{\mathrm{BOS}}=3.13651 \times 0.75=30715 \mathrm{kWh} \oplus
$$

\section{CONCLUSION}

Production of electricity using photoelectric power compared with traditional methods is certainly promising direction of power development. At the same time, the main limiting factors to refuse the traditional methods of power generation are Zeman (2014): The high cost per $\mathrm{kW}$ of energy produced by the photoelectric station, Low efficiency of photoelectric power stations compared to conventional (efficiency of modern gas power is $60 \%$, while the highest efficiency of most modern Eve gallium arsenide (GaAs) photoelectric cell, without taking into account the efficiency of the components of the 
photoelectric station, does not exceed $32.5 \%$ ), Strong dependence of the amount of energy produced by photoelectric power plant on average annual power of solar radiation (for Russia, the average annual power of solar radiation for different regions is $840-1.371 \mathrm{kWh} / \mathrm{m}^{2}$ ), which makes it impractical to use them in some regions.

\section{REFERENCES}

Anonymous, 2015. Common types of solar cells. Alternative Energy Inc., Pearl City, Hawaii, USA. http://www.altenergy.org/renewables/solar/commontypes-of-solar-cells.html.

Anonymous, 2017. Technical application papers No. 10 photovoltaic plants. ABB Automation Company, Zurich, Switzerland.

Batista, N.C., R. Melicio, J.C.O. Matias and J.P.S. Catalao, 2013. Photovoltaic and wind energy systems monitoring and building/home energy management using ZigBee devices within a smart grid. Energy, 49: 306-315.

Hussain, Q. and A. Uzair, 2013. Generating electricity by photoelectric effect. Solar, January 1st, 2013. https://swcphysics30.wordpress.com/2013/01/16/ge nerating-electricity-by-photoelectric-effect/
Inganas, O. and V. Sundstrom, 2016. Solar energy for electricity and fuels. Ambio, 45: 15-23.

Islam, M.A., M. Hasanuzzaman, N.A. Rahim, A. Nahar and M. Hosenuzzaman, 2014. Global renewable energy-based electricity generation and smart grid system for energy security. Scient. World J., Vol. 2014. 10.1155/2014/197136

Kang, D., S. Arab, S.B. Cronin, X. Li, J.A. Rogers and J. Yoon, 2013. Carbon-doped GaAs single junction solar microcells grown in multilayer epitaxial assemblies. Applied Phys. Lett., 102: 1-6.

Peake, S., 2018. Renewable Energy: Power for a Sustainable Future. 4th Edn., Oxford University Press, Oxford, England, UK., ISBN: 9780198759751 , Pages: 656.

Ren, Z., H. Liu, Z. Liu, C.S. Tan and A.G. Aberle et al., 2017. The GaAs/GaAs/Si solar cell-Towards current matching in an integrated two terminal tandem. Solar Energy Mater. Solar Cells, 160: 94-100.

Zeman, M., 2014. Integrating electricity from solar energy in electricity power system. Proceedings of the International Conference and Exposition on Electrical and Power Engineering, October 16-18, 2014, IEEE., Iasi, Romania, pp: 034-037. 